\title{
PENGARUH PEMBERIAN KRIM EKSTRAK BAWANG MERAH (Allium cepa) TERHADAP PROSES PENYEMBUHAN LUKA BAKAR PADATIKUS PUTIH (Rattus novergicus)
}

\author{
Asih Rahayu ${ }^{1}$, Adhitya Yoppy Ro Candra ${ }^{1}$, Kurnia Latif $^{1}$, Nurul Hidayah $^{1 *}$ \\ ${ }^{1}$ Fakultas Kedokteran Hewan, Universitas Wijaya Kusuma Surabaya \\ *Email: nurulhidayah78@uwks.ac.id
}

\begin{abstract}
This study aimed to determine the influence of onion extract cream (Allium cepa) for burning burns in white rats (Rattus norvegicus). The research was experimental with a concentration of $45 \%$, 50\%, and 55\% onion Cream Extract (Allium cepa). The Data can then be processed using the Kruskall Wallis test. From the statistical test results, each level of Bakart wound showed noticeable difference. The $P<0.05$ is thus distinct from P1, P2, and P3. At the level of fluid burns Sig 0.000, because $(P<0.05)$ There were noticeable difference in the treatment of $P O$ with $P 1, P 2$, and $P 3$. The conclusion of this study of the introduction of onion extract Cream (Allium cepa.) can be used for wound healing in white rats (Rattus norvegicus).
\end{abstract}

Keywords: shallots (Allium cepa L.), luka, white rats (Rattus norvegicus)

\section{PENDAHULUAN}

Luka bakar adalah kehilangan jaringan yang disebabkan kontak dengan sumber panas seperti air panas, api, bahan kimia, listrik, dan radiasi. Penanganan dan pengobatan luka bakar pada hewan harus segera di lakukan. Karena luka bakar dapat menyebabkan kematian dan cacat pada hewan (Barus dan Lestari, 2018). Proses penyembuhan luka terdiri dari tahap fase inflamasi, fibrolastik, dan pematangan. Tubuh kembali berusaha menormalkan kembali semua dengan proses penyembuhan secara alami. Dengan menggunakan zat tambahan yang di harapkan dapat membantu menghindari gangguan proses penyembuhan luka seperti infeksi, hematom, dan benda asing (Yunanda dan Rinanda, 2016).

Penggunaan obat tradisional di Indonesia menyimpan banyak potensi sumber daya alam hayati sebagai sumber bahan pangan dan obat-obatan. Bahan yang mudah di dapat dan biaya yang murah menjadikan pengobatan tradisional yang sering di gunakan. Pengobatan tradisional di nilai lebih aman apabila di gunakan sesuai dengan ketetapan dosis, waktu penggunaan, dan ketetapan cara pengguaan supaya tidakterjadi penyalahgunaan(Rubiah dan Djufri, 2017). Bawang merah (Allium cepa L.) merupakan salah satu tanaman hortikultura yang populer dalam dunia kuliner, sebagai bumbu masakan (flavor), sayuran (acar dan salad) dan produk olahan bawang goreng (Sari, dkk. 2017).

Bawang merah merupakan tanaman yang memiliki umbi, padakulit dan dagingnya berwarna ungu kemerahan. Bawang merah dapat hidup di dataran tinggi. Senyawa aktif yang dimiliki bawang merah yaitu Allisin dan Alliin, Flavonoid, Alilpropil disulfide, Fitosterol, Flavonol, Pektin, Saponin, Tripropanal sulfoksida, dansenyawa acetogenin. Senyawa flavonoid yang bersifat anti inflamasi serta anti mikroba sangat berguna untuk membantu proses penyembuhan radang akibat luka memar, luka bakar, atau radang pada organ tubuh dalam (Nilan, dkk. 2019). Bentuk sediaan topikal yang dapat dengan mudah digunakan untuk pengobatan pada luka bakar adalah salah satunya dengan pemberian sediaan krim. Penggunaan dalam bentuk sediaan krim lebih efektif. Berdasarkan pada penelitian sebelumnya dengan sediaan topical ekstrak bawang dapat membantu proses penyembuhan luka sayat pada mencit. Dengan kosentrasi 5\%, $30 \%$, dan 55\% ekstrak bawang merah (Allium Cepa L.) yang mempunyai nilai bermakna terhadap proses penyembuhan luka. 


\section{MATERI DAN METODE}

Jenis penelitian ini adalah penelitian eksperimental, penelitian ini menggunakan Rancangan Acak Lengkap (RAL) dengan teknik pengambilan sampel secara random/acak dengan menggunakan 5 perlakuan dan 5 kali pengulangan untuk masing-masing perlakuan. Sampel yang digunakan adalah tikus wistar jantan, umur 2-3 bulan, berat badan 200-300 gram.

Variabel dalam penelitian ini terdiri dari tiga variabel yaitu variabel bebas, variabel tergantung, dan variable kendali.

1. Variabel bebas pada penelitian ini berupa perlakuan dalam pemberian krim ekstrak bawang merah terhadaptikus putih dengan pemberian yang berbeda-beda sesuai kelompok perlakuan yaitu krim ekstrak bawang merah dengan konsentrasi $45 \%$, $50 \%$,dan $55 \%$.

2. Variabel tergantung pada penelitian ini berupa kebengkaan luka, cairan pada luka.

3. Variabel kendali pada penelitian ini berupa diameter luka bakar pada tikus putih (Rattus norvegicus).

Pembuatan ekstraksi bawang merah dilakukan dengan metode maserasi. Sebanyak $1 \mathrm{~kg}$ umbi bawang merah dikeringkan selama 7 hari, kemudian dikupas dan dipotong kasar. Umbi bawang merah yang dipotong dimasukan ke dalam tabung dan kemudian dimaserasi menggunakan pelarut etanol $96 \%$ sebanyak $500 \mathrm{ml}$.

Setiap 24 jam ekstrak tersebut disaring dan diganti pelarutnya dengan $300 \mathrm{ml}$ etanol 96\% yang baru. Proses maserasi ini dilakukan 3 kali sampai diperkirakan semua senyawa yang terkandung didalamnya terekstrak habis. Hasil maserasi disaring dengan menggunakan corong Buchner dan vakum. Ekstrak yang didapat kemudian diuapkan dan dipekatkan dengan evaporator tekanan rendah pada suhu $50^{\circ} \mathrm{C}$ sampai diperoleh ekstrak. Ekstrak kental yang diperoleh merupakan ekstrak dengan kosentrasi $100 \%$. Selanjutnya ekstrak tersebut diencerkan menggunakan aquades menjadi ekstrak dengan konsentrasi $45 \%$, $50 \%$, dan $55 \%$.

\section{HASIL}

Tabel 1. Rata-Rata dan Simpangan

\begin{tabular}{cc} 
Perlakuan & Mean \pm SD \\
\hline PO - & $18,50 \pm 0,000^{\mathrm{a}}$ \\
\hline $\mathrm{PO}+$ & $16,00 \pm 0,447^{\mathrm{a}}$ \\
\hline $\mathrm{P} 1$ & $13,50 \pm 0,548^{\mathrm{a}}$ \\
\hline $\mathrm{P} 2$ & $8,50 \pm 0,447^{\mathrm{ab}}$ \\
\hline $\mathrm{P} 3$ & $8,50 \pm 0,447^{\mathrm{ab}}$
\end{tabular}

Keterangan: Superskip yang berbeda pada kolom yang sama menunjukan berbeda nyata $(\mathrm{P}<0,05)$.

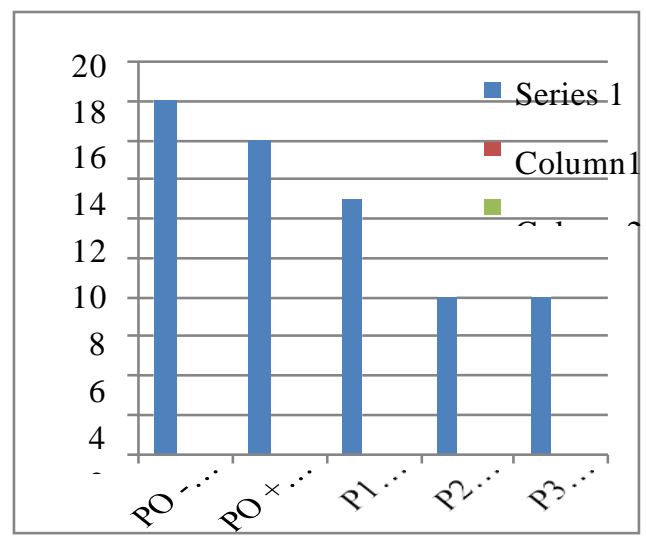

Gambar 1. Grafik Rata - rata Nilai Tingkat Kebengkaan Luka Bakar 
Rata-rata nilai tingkat kebengkaan luka bakar tertingi terdapat pada perlakuan (P0-) yang tidak di beri pengobatan yaitu 18,50 \pm Superskip yang berbeda pada kolom yang sama menunjukan berbeda nyata $(\mathrm{P}<0,05)$.

Tabel 2. Rata-Rata dan Simpangan Baku Nilai Tingkat Cairan Luka Bakar

\begin{tabular}{cc}
\hline Perlakuan & Mean \pm SD \\
\hline PO - & $23,00 \pm$ \\
& $0,000^{\mathrm{a}}$ \\
\hline PO + & $10,55 \pm$ \\
& $0,000^{\mathrm{b}}$ \\
\hline P1 & $10,55 \pm$ \\
& $0,000^{\mathrm{b}}$ \\
\hline
\end{tabular}

Nilai rata-rata cairan pada luka bakar diamati 14 hari adalah $23,00 \pm 0,000^{\mathrm{a}}(\mathrm{P} 0-)$, dan rata-rata pada perlakuan yang di berikan krim ekstrak bawang merah $(\mathrm{P} 0+),(\mathrm{P} 2)$ dan $(\mathrm{P} 3)$ memiliki rata-rata yang sama yaitu Nilai signifikan pada tabel kruskal wallis adalah $0,000(\mathrm{p}<0,05)$ maka terdapat perbedaan nyata terhadap perlakuan. Dari uji lanjutan dengan uji mann-whitney dapat dilihat bahwa kontrol () memiliki notasi a, kontrol positif notasi $b$, krim $45 \%$ notasi b, krim $50 \%$ notasi b, pasta krim $55 \%$ notasi b.

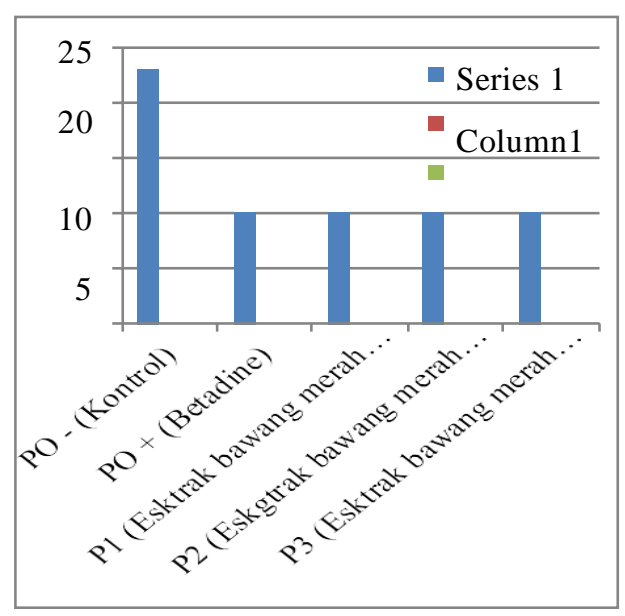

Gambar 2. Grafik Rata - rata Nilai Tingkat Cairan Luka Bakar

Rata-rata nilai tingkat cairan luka bakar tertinggi terdapat pada perlakuan (P0-) yang tidak diberi pengobatan yaitu 23,00 $\pm 0,000^{\mathrm{a}}$. dan rata-rata terendah pada perlakuan yang di berikan krim ekstrak bawang merah (P0+), (P2) dan (P3) 10,55 $\pm 0,000^{\mathrm{b}}$. Berdasarkan hasil penelitian menggunakan kruskal wallis, kesembuhan luka pada tikus (Rattus norvegicus) menunjukkan bahwa terdapat perubahan yang nyata. Dengan menggunakan uji lanjutan mann-whitney dapat dilihat perbandingan bahwa kontrol (-) dan perlakuan P1, perlakuan P2, perlakuan P3 terdapat perbedaan nyata.

\section{PEMBAHASAN}

Dari hasil pengamatan kebengkaan luka secara makroskopis dan analisis data menggunakan Uji Kruskal Wallis didapatkan hasil bahwa pada kontrol (-) mendapatkan hasil kurang baik dari semua perlakuan, dikarenakan tanpa pemberian krim ekstrak angka kesembuhan cukup lama dibandingkan dengan perlakuan yang lainnya karena tidak adanya obat yang bekerja untuk mengurangi rasa sakit apabila terjadi peradangan dan pendarahan (Haryani, dkk 2012). kesembuhan baru terlihat pada hari ke-14 luka sudah sembuh, dikarenakan pada kontrol (-) ini tidak diberi perlakuan pengobatan.

Kebengkaan pada perlakuan kontrol $(+)$ yang diberi pengobatan betadin dengan ratarata $(16,00)$ pada hari ke-13 terlihat luka tidak megalami kebengkaan dibanding kontrol (-) yang tidak diberikan pengobatan. karena povidone iodine $10 \%$ mempunyai kandungan yang mampu membunuh semua mikroorganisme penyebab infeksi nosokomial baik bakteri gram positif maupun negatif, termasuk mikroorganisme yang resisten terhadap spora, antibiotik, dan jamur (Rahmawati, 2014).

Pada perlakuan P-1 yang diberi pengobatan krim ekstrak bawang merah $45 \%$ dengan rata rata $(13,50)$ hari ke-13 terlihat luka tidak megalami kebengkaan. P-2 yang diberi pengobatan krim ekstrak bawang merah 50\% pada hari ke-12 terlihat luka tidak megalami kebengkaan. P-3 yang diberi pengobatan krim ekstrak bawang merah $55 \%$ pada hari ke-10 terlihat luka tidak megalami kebengkaan. P2 dan P3 menunjukan dengan rata-rata sama $(8,50)$ perbedaanya yang paling signifikan, hasil dari Skrining ekstrak bawang merah memiliki kandungan allin dengan kadar 2,36\%, flavonoid $6,11 \%$, dan saponin $4,05 \%$. Bisa disimpulkan bahwa di angka 50\% sudah cukup optimal Penyembuhan kebengkakan luka yang diberikan perlakuan ekstrak krim bawang merah (Allium cepa L.) lebih cepat karena mempunyai kandungan anti inflamasi yaitu aliin, flafanoid, dan saponin (Misna dan Diana, 2016). 
Dari hasil pengamatan cairan luka secara makroskopis dan analisis data menggunakan Uji Kruskal Wallis didapatkan hasil bahwa pada kontrol (-) mendapatkan hasil kurang baik dari semua perlakuan, karena kesembuhan baru terlihat pada hari ke-10 luka sudah sembuh, dikarenakan pada kontrol (-) ini tidak diberi perlakuan pengobatan masih cukup banyak cairan dikarenaken Fase inflamasi awal adalah darah akan memasuki jaringan yang terluka dan tercemarnya darah pada kolagen akan menyebapkan terjadinya pengaktifan faktor hemagen dan degranulasi trombosit hal ini yang menyebabkan cairan pada luka (Mufimah, dkk, 2019).

Cairan pada perlakuan kontrol (+) yang diberi pengobatan betadin pada hari ke-9 terlihat luka tidak terdapat adanya cairan dibanding kontrol (-) yang tidak diberikan pengobatan, Pada perlakuan (P1) yang diberi pengobatan krim ekstrak bawang merah $45 \%$ hari ke-9 terlihat luka tidak terdapat adanya cairan. Krim ekstrak Bawang merah (Allium cepa L.) dan betadine (Povidone-iodine) bisa untuk proses kesembuhan karena bisa memproses re-epitalisasi infiltrasi sel-sel radang pada jaringan luka yang memblokade cairan dan epidermis (Pongsipulung, dkk. 2012). (P2) yang diberi pengobatan krim ekstrak bawang merah $50 \%$ pada hari ke-9 terlihat luka tidak terdapat adanya cairan. (P3) yang diberi pengobatan krim ekstrak bawang merah 55\% pada hari ke-8 terlihat luka tidak adanya cairan. Semakin banyak kandungan tannin maka cairan pada luka semakin cepat terhambat karena tannin mempunyai peran untuk menetralisir protein inflamasi, menghambat hipersekresi cairan pada mukosa dan juga berfungsi sebagai antioksidan dan antimikroba yang memengaruhi penyambungan luka juga mempercepat epitelisasi (Kurnianto, dkk. 2017).

\section{KESIMPULAN}

Pemberian Krim ekstrak bawang merah (Allium Cepa L.) dapat menyembuhkan luka bakar pada tikus putih (Rattus Norvegicus). Kesembuhan luka bakar yang paling efektif dengan kosentrasi 55\%. Berdasararkan penelitian ini tentang luka luka bakar menggunakan krim ekstrak bawang merah (Aliium Cepa L.) perlu adanya penelitian lebih lanjut dengan kosentrasi yang berbeda dan dilihat juga secara mikroskopis terhadap proses penyembuhan luka.

\section{REFERENSI}

Barus. B, R. , I. Lestari. 2018. Pengaruh Ekstrak Umbi Bawang Merah dan Bawang Putih Terhadap Luka Bakar Pada Kelinci. Jurnal Farmasimed. 1(1): $1-5$.

Haryani, A., Roffi, G., Ibnu, D, B., Ayi, S, 2012. Uji Efektivitas Daun Pepaya (Carica Papaya) Untuk Pengobatan Infeksi Bakteri Aeromonashydrophila Pada Ikan Mas Koki (Carassius Auratus). Jurnal Perikanan Dan Kelautan. 3 (3); 218.

Jasmadi, R. N, Salim, A, Harris, 2016. Efektifitas Salep Getah Jarak Pagar 10\%(jatrophacuras linn) Dan Gentamisin $0,1 \%$ Terhadap Percepatan Penyembuhan Luka Bakar Derajat II Pada Kulit Mencit (mus musculus). Jurnal Medika Veterinaria. Fakultas Kedokteran Hewan. Universitas Syah Kuala. Banda Aceh. 10(2): 2503-1600

Kurnianto, S., Kusnanto., Padoli., 2017. Penyembuhan Luka Bakar Pada Tikus Putih Menggunakan Ekstrak Daun Pegagan (Centela Asiatica) 25\% dan Ekstrak Daun Petai Cina (Leucaena Leucochephala) 30\%. Jurnal Ilmiah Kesehatan.10(2) : 250-255.

Kurniawan, P, A, E. Hidayat, N. Wijoyo, H, S. 2018. Implementasi Metode Iterative Dichotomizer Tree Untuk Diagnosis Penyakit Pada Tanaman Bawang Merah. Jurnal Pengembangan Teknologi Informasi. Fakultas Ilmu Komputer. Universitas Brawijaya. 2(10) : 33913396.

Misna. K, Diana, 2016. Aktivitas Antibakteri Ekstrak Kulit Bawang Merah (Allium cepa L.) Terhadap Bakteri Staphylococcus aureus. Journal of Pharmacy. 2(2) : 138-144.

Mufimah., Hidayat, R, U., Budhiharto, I, 2018. Efektivitas Gel Ekstrak Bawang Putih Terhadap Proses Penyembuhan Luka Fase Inflamasi. Jurnal Vokasi Kesehatan. 4(2): 109-114. 
Rahmawati, I., 2014. Perbedaan Efek Perawatan Luka Menggunakan Gerusan Daun Petai Cina (Leucaena glauca) Dan Povidone Iodine $10 \%$ Dalam Mempercepat Penyembuhan Luka Bersih Pada Marmut (Carvia Porceolus). Jurnal Wiyata. 1(2): 227-234.

Rubiah. Djufri. Muhibbuddin. 2017. Etnobotani Tumbuhan Obat Luka Pada Masyarakat. Jurnal Edubio Tropika. Universitas Syiah Kuala. 5(2): 54-106.

Sari, V. Miftahudin, Sobir. 2017. Keragaman Genetik Bawang Merah (Allium cepa L.) Berdasarkan Marka Morfologi dan ISSR. Jurnal Agrom Indonesia. Institut Pertanian Bogor. 45(2): 176-182.

Yunanda, V. T. ,Rinanda. 2016. Aktivitas Penyembuhan Luka Sediaan Topikal Ekstrak Bawang Merah (Allium cepa) Terhadap Luka Sayat Kulit Mencit. Jurnal Veteriner. 17(4): 606-614 